\title{
Changing Fortunes: Criminology and the Sociological Condition
}

\section{ABSTRACT}

Criminology and its relationships with sociology are today at a crossroads, and this paper explores the changing fortunes of each as they have evolved over the last 50 years. The separation has occurred as criminology has successfully established itself as an independent subject with an impressive ability to attract students, scholars and research grants. Some see the striking expansion of criminology and move away from the basic disciplines as an indication of success and impressive achievement, while others are more sceptical and highlight the costs such isolation brings. The paper examines the consequences of these changes, then it focuses on the fates of some of the key concepts in sociological criminology, before concluding that social theory can be a unifying force, capable of reinvigorating the ties between the two disciplines.

\section{KEYWORDS}

Cultural studies, deviance, social theory, subculture

Author: Professor Eamonn Carrabine, Department of Sociology, University of Essex, Wivenhoe Park, Colchester, Essex, CO4 3SQ. Email: eamonn@essex.ac.uk.

This anniversary issue of Sociology, marking 50 years of the journal, offers an opportunity to reflect on the relationships between criminology and sociology as they have developed over this time. Where once the ties had been strong today that is no longer case. Criminology is now not content to see itself as a subfield of the legal, medical or social sciences. The separation has occurred as criminology has successfully established itself as an independent academic subject, either breaking away from law schools and sociology departments or sitting uncomfortably within them. In many of the latter criminology student recruitment exceeds that to sociology, posing thorny questions on the future shape of both in competitive, 
market driven, mass higher education systems. The paper begins by concentrating on the consequences of these changes, then it describes how some of the central concerns in sociological criminology have fared over this time. In particular, it focuses on the concepts of 'deviance' and 'subculture', charting their fates before concluding that social theory can be a unifying force, capable of reinvigorating the ties between the two disciplines.

In Britain the close relationships between criminology and sociology only really emerged in the 1960 s, with the establishment of a university system that was particularly receptive to the new discipline of sociology ${ }^{1}$. Once the expansion was well under way this generation became disillusioned with the medico-legal character of British criminology. As these sociologists began to study such topics as drug taking, youth cultures and mental illness they found themselves 'doubly marginalized' (Downes, 1988:46) by both their own discipline and orthodox criminology. In his indispensable essay on these developments, Cohen (1981/1988) describes how a radical approach to crime and deviance was conceived in 1968 by the formation of the National Deviancy Conference (NDC). One indication of the incredible intellectual ferment is that in the first five years of the NDC, from 1968 to 1973 there were 63 speakers from Britain at 14 conferences, who between them produced just under 100 books on diverse topics (Young, 1998:16), ranging from the phenomenology of suicide to industrial sabotage, as well as a series of classic analyses of class and youth that are among the main legacies of the NDC. It gave a platform for critical work to flourish, including Taylor et al's (1973) rallying call for a 'new criminology', which succeeded in differentiating radical European analysis from the American study of deviance and became 'the Bible' for a generation (Reiner, 2012:35). 
Soon internecine conflicts rose over the different directions critical work should take, but not before the approaches pioneered at the NDC became established in the academic field. By the time of the last conference in 1979 they had fractured along the same rifts as sociology more generally, acrimoniously disputing the merits of Marxist, Feminist and Foucauldian approaches then dominant. According to one of the central figures, it "was a dizzying scene, more a paradigmatic kaleidoscope than a clear-cut progression of superior paradigms delivering a knock-out blow to the inferior' (Downes, 1988:49). But what is clear is that the radical approaches associated with the NDC had considerable impact in British sociology. Cohen (1981/1988:84-86) concludes his review of the then state of play by highlighting how subfields of sociology were hospitable to new deviancy ideas - including education, medicine, mass media, welfare and social policy, as well as cultural studies and a revival of interest in the study of law as a social institution.

The sense of schism gave a 'useful order to an emerging field' (Rock, 1988:191), while the new perspectives themselves became institutionalized and respectable. Ironically, it was radical, sceptical and critical versions of criminology that fuelled the remarkable growth of the discipline in the decades to come as the commodification of higher education took hold in the 1990s. Since then criminology has acquired the organizational trappings of an academic discipline (Loader and Sparks, 2012:8). These include the growth of separate departments, new degree schemes, graduate research funding, large annual conferences, prestigious prizes and the appointment of researchers whose entire higher education experience has only been in criminology. The following passage captures some of the issues at stake:

In the last decade or so, and for the first time in its history, criminology has sought to establish firm parameters on what is and what is not classed as "criminology". It does this by creating a myth about its own history and then 
enshrining it as "fact". For years criminology was happy to acknowledge that it was essentially an importer of ideas and theories from cognate fields and more firmly established academic disciplines across the social sciences and humanities. It also acted as a meeting place of sorts, an intellectual space into which academics from different disciplinary backgrounds could come to debate the causes of and control of crime and social harm. In recent years there seems to have been a gradual erosion of this very positive intellectual firmament.

(Hall and Winlow, 2012:8)

The central message from these authors is that it is now time for the discipline to recover its vitality and vigour in the face of such obstacles and this paper shares their ambitions to renew and extend the theoretical gaze of criminology, but does so through directly engaging with the sociological condition itself and identifying two very directions of travel available. One might be termed the 'imperial' conceptualisation and the other offering a more 'cosmopolitan' vision of sociology and social theory.

\section{Expansion and Specialization}

The dangers of an ever narrowing specialization are that the field is 'at risk of sinking into a set of cliques where criminologists read the work of others who think like them, write for those very same people and publish only in the journals that they and their colleagues are already reading' (Bosworth and Hoyle, 2011:3). A similar point has been made by Hobbs (2012:262) where he describes the current 'tendency of criminologists to Balkanise themselves, often preaching to the converted via specialist outlets and citation clubs, has drastically reduced the potential impact of their scholarship, exacerbating the retreat from sociology, and severely restricting criminology's range'. Equally this is a major problem for sociology, where whole sub-fields of the discipline migrate and establish themselves as new 
areas or applied subjects, as health studies, social policy, media studies and others have done so in Britain - at some cost to the overall coherence, institutional reputation and well-being of the discipline (Holmwood, 2010). Likewise, much of the sociology of work is now to be found in business and management schools and will lead to a dilution of the 'sociological imagination' in these environments (Halford and Strangleman, 2009:819).

The rapid expansion of criminology is not just restricted to Britain, it has been especially pronounced in the United States. According to the American Sociological Association (ASA), criminology and criminal justice majors now outweigh those enrolled on sociology programmes by some two thirds (Hannah-Moffat, 2011:450). In the US the movement towards independent criminology and criminal justice programmes was already well advanced and many are vocational, posing awkward questions over whether criminology is actually an academic discipline at all. It is not simply that criminology has divorced itself from sociology in the US. Sociology has also 'pulled away from criminology, particularly as taught and studied at elite institutions' (Short, with Hughes, 2007:632). The expansion of an applied, practitioner-orientated criminology has adversely impacted on the subject's intellectual status (Garland, 2011:311). In Europe the pattern is more mixed, but criminology departments and degrees have rapidly increased in Canada, Australia, New Zealand, and South Africa, with many beginning to appear in India, China, and Asia (Loader and Sparks, 2012:9-10). Criminology is now taught around the globe, and it is important to consider the implications of these changes, not least since the discipline itself exists in a world experiencing immense transformations.

Indeed, the scale of the cultural, economic and political changes that have gathered pace since the late twentieth century present profound challenges. As Garland and Sparks (2000:1) put 
it, to wish these difficulties away, 'to carry on regardless, to pursue the conventional agendas of criminological enquiry in the accustomed way, would be to turn away from some of the most important issues that face contemporary social thought and public policy.' These comments introduced a collection of essays seeking to renew and invigorate the field, initially published as a special issue of the British Journal of Criminology and then an edited book. Many of the contributors are leading social thinkers (including Zygmunt Bauman, Mary Douglas, Paul Hirst and Nikolas Rose), but who are rarely thought of as 'criminologists' even though their work speaks directly to issues at the heart of criminological enquiry. More recently the NDC has been revived in 2011 and 2014, as the organisers felt that it was 'very much needed, especially in Britain, as the dominant conferences were once again becoming increasingly administrative and empiricist in nature' (Winlow and Atkinson, 2013:17). There is a clear sense that the field is struggling to understand a world in flux and is missing the big picture, a long standing complaint, but made all the more pressing given the intellectual and political challenges of our times.

From the outset many of the leading figures insisted that criminology is not a discipline, and the entire NDC movement can be seen as a form of 'anti-criminology', which has gradually had to 'absorb the implications of its own creations' (Cohen, 1988:16). In one recent assessment British criminology continues to be wedded to a stolid mix of 'correctionalism, modernism, abstracted empiricism, unprincipled eclecticism and positivism' (Rock, 2011:21). These accusations are regularly levelled against the field to denounce the character of much scholarship. For some, contemporary criminology has all the organizational trappings of an academic discipline, but has no intellectual core around which the diverse approaches and specialty areas can cohere. The worry is that an 'independent criminology' will further 
'fragment into distinct specialisms' with an increasingly inward focus resulting in 'negative consequences for collective learning' (Garland, 2011:312).

In the US context Abbott (2001:134) has noted how 'status differences' work to keep certain hierarchies in place: 'Criminology departments hire from sociology departments, but seldom vice versa'. Here conventional disciplines have been able to maintain their dominance, despite a plethora of applied subject areas growing around them. Abbott explains how a fairly long historical process has shaped a structure of flexibly stable core of disciplines, surrounded by heady blur of interdisciplinarity, where the conventional disciplines stand in superiority. Academics compete with one another through redefining each other's work. This movement is rarely a two-way exchange of ideas, developments in the applied field are seldom translated back into the primary field. Crucially, the applied areas are not selfreproducing, but rely on the "continued importation, and, in consequence on the health of the exporter disciplines' (Holmwood, 2010:646). The strong departmental structure of the US university system has helped to sustain the disciplinary status of sociology, but the prospects in the UK are bleaker in Holmwood's reckoning, due to the twin threats of interdisciplinarity and the audit culture regulating higher education in the country (though see Savage, 2010, for a nuanced critique of this view).

The expansion of criminology has 'marginalised critical writing and reduced theory from a live contested quality that ran like a thread through all aspects of scholarship to a niche or specialism' (Hobbs, 2012:262). This tendency was identified over 15 years ago in the US, where Currie (1998:18) distinguished between three divisions in American criminology: a large, technocratic, 'mainstream' that rarely ventures into the public arena; a small, but extremely vocal and influential right wing set of commentators; and a slightly larger radical 
ghetto, which is content to go 'along with the definition of itself as a fringe, or as a kind of sub-specialization within the larger field.' For Abbot (2001) this fragmenting is part of the normal 'chaos of disciplines' and a healthy sign of well-being, as disciplines cycle through a pattern of core principles. In discussing this argument Holmwood (2010:649-50) maintains there is rarely any agreement on what constitutes the organising core of sociology, meaning that it constantly 'has to be achieved against an internal tendency to self-subversion' and this might be best seen as 'a particular kind of "dissensus".

Sociology has diversified and fragmented to such an extent that it is now far less possible to claim a clear centre to the discipline (Urry, 2005), but important questions remain over the kind of relationships sociology should be cultivating with other disciplines in the social sciences and humanities (Scott, 2005). Few would insist on 'any kind of isolationism for sociology' nor argue against 'multidisciplinarity', but in a context where there is 'a strong sense of what different disciplines can bring to debate, not the collapse of disciplines into indistinctiveness' (Halford and Strangleman, 2009:821). Scott (2005) builds his argument from some questions initially posed by Urry (1981) over two opposing conceptualisations of sociology: one sees it as the Queen of the Sciences, in a Comtean sense, standing at the head of a hierarchy of disciplines, while the other views it as a parasite - scavenging off the discarded remnants from more autonomous disciplines resulting in a disparate mix of 'sociologies of' one thing or another. Such an approach might be called 'promiscuous' but a more generous reading would be to describe it as a 'cosmopolitan' vision, which is an orientation Outhwaite (2015:121-2) commends in his recent overview of social theory and stands in contrast to the 'soft imperialism' of sociology. Both frames of reference carry risks, but the cosmopolitan is a broader approach, spanning the social sciences and bridging the divide with the humanities, but 'feeling not quite at home anywhere' (ibid.). 
Although Urry (2005:1) maintains there must be 'strong and coherent disciplines', as there is 'nothing worse than lower common denominator interdisciplinarity', he does point out the opportunities fragmentation provides, helping to enliven and transform mainstream concerns. But the problem, once we consider sociological criminology, is that some of its central concepts - deviance, moral panic, social control, subculture to name just a few - no longer command the attention they once did and sound like ideas who have run their course. As topics they remain popular on undergraduate modules and dissertations, but not many would say they are at the cutting edge of contemporary thinking. Of course, this waxing and waning of interest in particular concepts is an endemic feature of scholarship, paradigm shifting eruptions are inevitably followed by patterns of 'normal science' then a winding down and eventual exhaustion, once there is little new to say and remain dormant until revived by a fresh intervention restarting the cycle. But this is not to say that the processes they describe or the questions they pose disappear, rather they are reworked in different settings and it is this dynamic I explore in what follows.

\section{Deviance and Difference}

One of the consequences of the recent expansion of criminology has been the proliferation of seemingly new theories of criminality. Often these new approaches are revisiting older sociological ideas, but with sophisticated quantitative research methods and mobilising statistically testable propositions. For example, anomie has been revived in 'general strain theory' (Agnew, 1992), social disorganization is reincarnated as 'collective efficacy' (Sampson et al, 1997), deviant careers are now understood through the lens of 'life-course criminology' (Bonistall and Ralston, 2014), differential association underpins 'social learning theory' (Akers and Jensen, 2003) and the ascendancy of rational choice in all manner of 
'control' theories (Clarke and Felson, 2008). If the earlier sociologists could be accused of romanticising deviance, then these newer theories have gone too far in portraying crime as 'mundane' (Best, 2004a:75). A move challenged by the revival of interest in cultural criminology over the last two decades, where the term transgression (Presdee, 2000, Ferrell et al, 2004) has been deployed to attend to the phenomenology of crime and rule breaking. Simply put, it is an approach that has attempted to place the study of crime and its control firmly in the context of culture, viewing them as creative constructs full of energy and meaning. The major task remains one of constructing 'a fully social theory of crime and deviance that does not maintain that there is a sociology of "normal" people and another discipline seeking to explain crime and deviance' (Young, 2013:xiv).

These words were written by Young in an essay introducing the $40^{\text {th }}$ anniversary of the publication of the New Criminology, one of the most well-known books to emerge from the NDC. In it he situates the book in a critical sociology inspired by Mills' (1959) The Sociological Imagination. This new essay picks up arguments from Young's (2011) final book, which subjected criminology to a similar withering attack that Mills delivered upon sociology over fifty years ago. In it he condemns the 'abstract empiricism' of mainstream criminology, described as one-dimensional, banal, technocratic and in the deadening grip of quantification, while that which aspires to 'grand theory' is also divorced from social realities, thriving on trivial, ponderous obfuscation where 'latter-day Foucauldians have taken an outrageous and iconoclastic thinker and turned his writings into some sort of Talmudic parody of contested interpretation' (Young, 2011:6). This ambition is not without its own problems, discussed elsewhere (Carrabine, 2015), but it is significant that the new criminology project was dedicated to a 'fully social theory of deviance' and it is this 
emphasis on social theory that I see as the unifying force capable of reinvigorating the ties between criminology and sociology.

It is worth recalling that the concept of deviance, from Durkheim onwards, was always meant to be a broader notion than criminal behaviour, while also being less insulting to individuals and groups who departed significantly from social norms. As Goffman pointed out in the 1960s, when the field was thriving and brimming with intellectual energy, it was only ever sociologists who thought it useful to group together drug takers, prostitutes, jazz musicians, the urban poor, circus performers, and the mentally ill under a single concept and then think they have enough in common that significant things can be said of them as a whole (Goffman, 1963:167, n.1 and 170-1). As such the key quality is difference, and how this is bound up with cultural conflicts, social judgements and political processes. In Stigma, Goffman (1963) examined how people managed 'spoiled identity', the pain and shame associated with being considered less than human and exposed the very inappropriateness of the term deviance to describe physical handicap, ethnic difference and numerous forms of social disaffiliation.

Indeed, the sociology of deviance came under sustained attack for its internal contradictions and inability to confront larger questions of power, control and ideology. The demise of the concept is captured in books like Pearson's (1975) The Deviant Imagination, which argued that the romanticization of crime, deviance and illness in 'misfit sociology' was a dead end. Although the concept of deviance was further reworked at the Birmingham Centre for Contemporary Cultural Studies (CCCS) it became subsumed under broader debates surrounding culture, ideology and politics. By the 1980s cultural studies had moved on to questions of difference, identity and postmodernism, while a major 'obituary' from the 1990s 
claimed the entire 'field had died' (Sumner, 1994:ix). Of course, the irony in the UK was that this assessment was written just as criminology, as a distinct discipline, began to take flight. In the US reactions noted that the sociology of deviance had lost much of its intellectual energy where the rapid growth of criminal justice as a vocational discipline had taken its toll, concluding that the concept was still alive, but not all that lively (Best, 2004b).

The metaphor of transgression has replaced the central concerns in the sociology of deviance, where old questions are now put in a fresh light. Conceptually it takes 'us along a series of continua, both vertical and horizontal, such as sacred-profane; good-evil; normalpathological; sane-mad; purity-danger; high-low; centre-periphery and so on' (Jenks, 2003:2). The key dynamic is the sense of 'trespass', of stepping beyond prescribed limits, breaking rules and exceeding boundaries, where the 'trouble' is as much 'inside' as it is 'outside' (Jervis, 1999:3). Of course, these ideas have resurfaced in cultural criminology (Ferrell et al, 2008), which has done much to emphasize the role of image, style and meaning in subcultures and the mediated processes through which crime and punishment are constructed.

Pivotal has been Katz's (1988) account of the sensuality of crime across a diverse range of acts, which include juvenile 'sneaky thrills', armed robbery and cold-blooded, 'senseless' murder. The book was highly provocative and intended to restore the rich, interpersonal drama of the illicit by highlighting the 'moral emotions', such as shame and humiliation, in a nuanced phenomenology of the moment. Although influential it has been criticised for disregarding the wider social context in which all action takes place (Young 2007), failing to secure 'serious distance' (implying that offending stories are taken at face value) and lacking any 'systematic explanation' of the various 'motivational' accounts (Taylor, 1999:224). Yet, 
as Hayward (2002:83) suggests, these objections ignore "the failure of "background" structural theories of crime to address the fundamental question of why (under shared social conditions) one person rather than another commits crime'. This is a crucial point and suggests that there remains a troubling split between structure and agency and a need to reconcile the rich, existential focus of his work with an understanding of structural forces and historical processes giving shape and meaning to lives that transgress.

In this regard, Lyng's (1990) concept of 'edgework' has been telling, as he combines both Marx and Mead in an effort to place voluntary forms of risk taking in a broader social context. Here the 'problem of consciousness' is the link between macro-level economic forces (Marx) and social interaction at the micro-level (Mead). The 'edgework' concept itself is taken from the journalist Hunter S. Thompson and his depiction of anarchic, excessive conduct, most famously in his hallucinatory account of Fear and Loathing in Las Vegas, where 'negotiating the boundary between life and death, consciousness and unconsciousness, and sanity and insanity is a central theme' (Lyng, 1990:855). Various types of dangerous sports (rock climbing, skydiving, downhill skiing, motor racing and so on), risky occupations (firefighting, test piloting, combat soldiering and police work) and illicit sensations (binge drinking, drug use, body modification, sadomasochistic sexualities, eating disorders and outlaw bikers) are among the practices identified as involving edgework.

Not unsurprisingly the focus in edgework studies on prototypically male, high-risk endeavours has been criticised by feminist criminologists. One of the earliest critics highlighted how the examples are almost all 'activities that are engaged in primarily by white men with attachment to the labor force' (Miller, 1991:1531). Drawing on her own research with African-American, female street hustlers Miller contends that their daily oppression is 
such that they have to engage in edgework to a far greater extent than working or middleclass men and because of their structural location they rarely do so voluntarily. Since then attention has been given to the gendered dynamics of offending and examining the ways multiple inequalities intersect and interlock to render some subordinate while reinforcing the privileges of others. Indeed, Cain (1990:6) was an early advocate for a 'transgressive criminology' urging feminists to step outside the confines of conventional 'criminological discourse' and instead 'raise questions about our constitution of gender itself' in an effort to unravel the conditions that disadvantage both men and women (see also O'Neill and Seal, 2013).

Cultural criminology has also been criticised from the different strands of realist criminology currently enjoying a renaissance. Steve Hall and Simon Winlow (2007) in an initial polemic denounced the celebratory idealism, romanticising of the offender, and failure to grasp the full implications of neo-liberal capitalism's destructive power in much cultural criminology. Across a series of subsequent publications they have continued the critique, most recently explaining that cultural criminology 'is not really criminology, it's the sociology of peripheral mischievousness' having little to say on serious and harmful crimes like 'domestic violence, homicide, and violent organized crime, yet it also fails to investigate state and corporate crime, which it leaves to more traditional critical criminologists' (Hall and Winlow, 2015:51). Their own approach, dubbed 'ultra-realism', is derived primarily from contemporary radical philosophy, which they strive to differentiate from the more familiar Left realist position that emerged in the mid-1980s (itself a reaction against the 'idealism' of the NDC). A leading proponent of Left realism, Roger Matthews (2014) has attempted to reconfigure cultural criminology along realist lines so that it produces work that has policy relevance, while combining theoretical curiosity with empirical rigour. Here there is a long 
overdue attempt to align his social democratic project with critical realist writers such as Margaret Archer, Roy Bhaskar and Andrew Sayer, who were oddly ignored as the perspective took shape in the 1980s and 1990s. These are important theoretical interventions and I return to them below, for there are significant differences between them, but what they do point to is the urgent need to revitalize criminological thought.

\section{The Subcultural Legacy}

The concept of subculture sought to explain how differences between a particular social group and the mainstream come to be defined as deviant, defying the beliefs, lifestyles, manners, values of the larger society. In what follows I briefly trace the legacy of the subcultural tradition as it was developed by Stuart Hall and his colleagues at the Birmingham Centre for Contemporary Cultural Studies (CCCS), to see how the concept of deviance and the subcultural terrain became subsumed under broader debates surrounding culture, ideology and politics. The last twenty years have seen the growth of 'post-subcultural' studies emerging to address the criticisms associated with the Birmingham tradition (Sweetman, 2013). These new perspectives have difficulties of their own, not least since the outright rejection of this past leaves a 'valorizing of individual consumption' that fails to grasp 'the generation or articulation of deviance as social experience' (Blackman, 2014:506).

The subcultural tradition, as it evolved through the Chicago School up to the Birmingham Centre, always sought to portray subcultures as distinctive social worlds - deviant, disenfranchised and unconventional, but forming ties with others sharing similar values, practices and geographies. The CCCS established an approach that no longer saw subcultural formations as a frustrated readjustment to dominant middle class values, but a defiant opposition to them. The rise of spectacular youth subcultures in post-war Britain were read as 
signifying the predicament of social change and distilling the bitter dynamics of class conflict in the shift to a modern, consumer society (Hall and Jefferson, 1976). However, this resistance occurs in the fields of leisure and consumption, thereby failing to challenge broader structures of power. This theme is developed in Willis's (1977) ethnographic study of how a 'counter-school culture' among a group of working class 'lads' ultimately prepares them for menial, unskilled employment. The meanings of subcultural style are explored with considerable verve by Hebdige (1979) through a mix of textual analysis and case studies where the interest in the working class is retained, but is now situated in the subversive potential of Continental avant-garde aesthetics. The lasting impact of the book, and the CCCS approach more generally, is to pit youth subcultures against the incorporating logics of mass culture.

Critics quickly disputed the political significance attached to subcultures in the approach and were troubled by the elitist focus on the original, authentic moment at the expense of any sense of a lived culture (Clarke, 1981). Others found fault with the romantic reading of youth style as internal to the group, which underestimates the ways youth subcultures are manufactured by culture industries (Cohen, 1980). Concerns were raised over the preoccupation with white, male and working class subcultures, where the celebration of the spectacular ignored the racism and sexism in them. However, the Marxist emphasis on class was contested by feminists at the Centre, most notably by McRobbie (1981) who highlighted how Willis and Hebdige had implicitly privileged masculinity and ignored relationships in the family, households and sexuality. Much of her work ever since has been a sustained, gendered interrogation of social change and a tracking of how consumerism borrows some of feminism's central concerns, while at the same time diluting and undermining their critical meaning and impact. 
The relative neglect of ethnicity is a criticism that needs to be addressed in more detail, not least since Hall and his colleagues begin to track the politics of race in their major work on Policing the Crisis (Hall et al, 1978). Yet the very 'Englishness' of the cultural studies project remained unexamined until the Empire Strikes Back (1982) collection of essays, which argued for a more critical take on the social construction of race. Gilroy (1987:12) subsequently condemned the "morbid celebration of England and Englishness from which blacks are systematically excluded' in the discipline. He subsequently denounced essentialist accounts of black cultural formations, insisting they produce 'camp mentalities' echoing not only fascism but also the commercialisation of African-American music and urban, ghetto styles. In the latter new claims of ethnic authenticity chime with twenty first century corporate multicultural commodification: when 'hip-hop's marginality' becomes 'as official and routinized, as its overblown defiance, even if the music and its matching life-style are still being presented - marketed - as outlaw forms' (Gilroy, 2000:180). His critique of biopolitics is also extended to how the black body is coded as either super human in the black athlete or as less than human in the violent black criminal. Notions of 'ghettoness' have become synonymous with forms of transgressive 'otherness' (Jaffe, 2012), but his more recent work has explored the 'convivial culture' of multicultural cities, where forms of tolerance jostle with racism and yielding fresh insights into the relationships between the metropolis, colony and the 'immigrant' (Gilroy, 2004).

The focus on identity and difference was bound up with broader changes across the intellectual landscape, where the era of 'the Post' came to characterise these new times: postcolonialism, post-feminism, post-fordism, post-marxism, post-structuralism, and looming over all, the post-modern. In Hebdige's (1988) Hiding in the Light he sets out to overcome 
the weaknesses of subcultural analysis by exploring debates over postmodernism. Early on we learn that this will be an 'obituary' for his initial 'theoretical models' where the 'idea of subculture-as-negation grew up alongside punk, remained inextricably linked to it and died when it died' (Hebdige, 1988:8). This idea reworked by Redhead (1997) and others who argued that the subcultural moment had now passed into history (between the death of punk and the rise of rave later in 1980s) and the movement to 'club cultures' required fresh postmodern theorising.

Consequently, terms like 'tribe', 'scene' and 'lifestyle' have been advanced to deal with the problems associated with subcultural theory. The suggestion is these are better equipped to capture the proliferation, fragmentation and individualised character of contemporary youth cultures (Bennett, 2011). Others criticised CCCS subcultural approaches for over relying on theoretical abstraction at the expense of empirical data (Hodkinson, 2012). Significantly, Hall and Jefferson (2006) have responded to these criticisms in a wide ranging survey of how their approach has fared. In discussing some of the main post-subcultural contributions they note they certainly provide:

fuller accounts of the lived accounts of the lived experiences of their subcultural "bearers" better than we did in $R T R$, thereby meeting the main thrust of the "lackof-ethnographic-authenticity" critique. But, beyond that, what do we learn of the larger picture? How well are these empirically grounded subcultures "grounded" in relation to the political, economic and socio-cultural changes of their respective times? The answer is "not very well", if at all.

(Hall and Jefferson, 2006:xiv) 
This is partly due to an 'endemic problem with ethnographic accounts' where insider depictions 'told from within is taken to be the privileged level of enquiry and of explanation' and some are fundamentally 'opposed to...making connections between lived experience and structural realities' (ibid.) Their line of critique here is accuse the post-subculturalist ethnographers of offering up a 'hollow empiricism' that fails to grasp the larger, structural condition and ties to historical developments (Sweetman, 2013:2).

On one level the tensions exposed here are between cautious, ethnographic work and big picture, sociological theorising, but on another they speak to the question of how are we to distinguish between good and bad ethnography - from 'thick' and 'thin' description - and returns us to themes introduced earlier in this paper. Matthews (2014:208) spends some time setting out what to 'critical realists a good ethnography' should look like and argues it should include a number of key attributes, and insists they must:

be evaluative of social action and aim to better understand human capabilities, vulnerabilities, and values. People's involvement and response to different forms of transgression are not reducible to the search for excitement, engaging in "edgework", the experience of resistance, or even the joy of transgression. We need to understand more about the ethical dimensions of social life and the complex mix of values, aspirations and concerns of those we study...Some account also needs to be taken of public opinion and social norms to understand why different forms of crime and deviance matter to people.

(ibid.)

The two exemplars he chooses to support his case are Willis's (1977) Learning to Labour and Goffman's (1968) Asylums, both of which begin with particular situations and move out to 
more general forms of explanation, through a process of abstraction that identifies the essential features of the processes and institutions under study. In this article Matthews is emphasizing the role of theory, and his overall project is geared toward building a critical realist approach that goes beyond 'so what' criminology (see also Matthews, 2009). There is no doubt criminology is in urgent need of theoretical renewal, but a complaint is that 'he moves us further away from genuine critical realism and closer to the administrative pragmatism that bogged down left realism in the 1980s' (Hall and Winlow, 2015:63).

As mentioned earlier Hall and Winlow have been developing their own 'ultra-realist' position and this denunciation is bound up with this project. It is heavily influenced by the radical philosophy of Badiou, Rancière, Virilio and Žižek, among others, written in a deliberately provocative style they attempt nothing less than the deconstruction of the dominant paradigms of criminological thought. But it is a bleak and often one-dimensional take on social relationships, while the relentless drive to demolish left-liberal scholarship has the unfortunate tendency to overshadow the originality of their own insights. Nevertheless, I share their desire to revitalize criminology and could not agree more with their contention that we:

no longer live in the 1960s, and whilst we should respect some of the major theoretical accomplishments of the past, we should not slavishly regard this particular period as the pinnacle of human thought and attempt to make its theories fit into a very different political, economic, cultural and ideological climate. Instead, we should, in an exercise shorn of sentimental attachment and vested interests, take from those theories what remains vital and pertinent before redoubling our efforts to make sense of the world as it is and as it could be. 
This motif of recognizing the new without losing sight of what is still valuable in the old serves as an invaluable blueprint for how theoretical work in the social sciences should proceed.

\section{Conclusion}

One of the consequences of the striking expansion of criminology over the last twenty-five years or so has been the development of distinct specialisms and the invention of an entire criminological tradition. But somewhere along the way it lost 'its sociological soul' and nowhere is this more apparent than in the 'false dichotomy that has been created in British criminology between the economic and the cultural' (Hobbs, 2012:262-3). Earlier in this paper I mentioned that the new criminology project was dedicated to developing a 'fully social theory of deviance'. Famously it never delivered on this promise, and the work that is often said to have come the closest is Hall et al's (1979) Policing the Crisis, but there are others - not least Taylor's (1999) own Crime in Context, that combines a nuanced understanding of the political economy of crime with a thorough handle on its cultural dynamics in competitive, market societies. A different kind of example would be Garland's (1990) Punishment and Modern Society, which was a wide ranging survey of the classic social theorists who have explored the institutional complexity of punishment, to reveal the broader structural forces, cultural sensibilities, political conflicts and social relations sustaining penal systems. More recently Hobbs's (2013) Lush Life is the culmination of decades of ethnographic research highlighting the flexible nature of criminal markets, the constructed and contested notion of organized crime, which interacts with upper and underworlds, and increasingly normalised in the evolving complexities of urban living. 
These are only a handful of examples and readers will no doubt be able to call on others, but my more general point is that criminology needs to renew its relationship with the sociological imagination. And this should not be a one-way street, especially since social theory itself is understood to be in a state of crisis, where today there are at best 'highly idiosyncratic treatments of theory in a few sociology departments and a small theory community among the students in those departments' (Turner, 2009:558). Although Turner is describing the teaching situation in the United States, where the position is undoubtedly extreme, but the modularization of courses elsewhere has meant that few students are now acquiring a thorough grounding in the classic, formative debates or a comprehensive sense of the contemporary theoretical landscape. At the moment there are two directions in which academic social theory can go. One will further contribute to disciplinary fragmentation, where academic social theory establishes itself as 'a kind of sub-discipline, distinct from the main fields of philosophy, sociology, politics and so on', the other is a more 'cosmopolitan' approach spanning divisions between social science and the humanities, and 'including the social thought generated by social movements and others outside the academy' (Outhwaite, 2015:121). It seems to me that is a welcome move away from the Comtean 'imperial' vision of sociology toward 'an intellectual space in which sociology and its "others" coexist and hybridically operate in a variety of settings, of which universities are only one element' (Stanley, 2005:1.9). Criminology is just one of the 'others' that have grown out of a sociological specialism, but the challenges it presents to the intellectual jurisdiction of the discipline are serious and demand extended consideration, of which this paper is only a beginning.

\section{Acknowledgements}


I would like to thank the two anonymous reviewers for their helpful comments on the initial version of this paper, and to the editors of the journal for all their assistance.

\section{References}

Abbott, A. (2001) Chaos of Disciplines, Chicago: University of Chicago Press.

Agnew,R. (1992) 'Foundation for a General Strain Theory of Crime and Delinquency', in Criminology, 30:47-87.

Akers, R. and G. Jensen (2003) Social Learning Theory and the Explanation of Crime: A Guide for the New Century, Boston, MA: Northeastern University Press.

Bennett, A. (2011) 'The Post-Subcultural Turn: Some Reflections Ten Years on', in Journal of Youth Studies, 14/5:493-506.

Best, J. (2004a) Deviance: Career of a Concept, Belmont, CA: Wadsworth.

Best, J. (2004b) 'Deviance may be Alive, but is it Intellectually Lively? A Reply to Goode', in Deviant Behavior, 25:483-492.

Blackman, S. (2014) 'Subculture Theory: An Historical and Contemporary Assessment of the Concept for Understanding Deviance', in Deviant Behavior, 35:496-512.

Bonistall, E. and K. Ralston (2014) 'Deviant Career and Life-Course Criminology: Using Street Prostitution', in Anderson, T. (ed.) Understanding Deviance: Connecting Classical and Contemporary Perspectives, New York: Routledge.

Bosworth, M. and C. Hoyle (2011) 'What is Criminology? An Introduction', in Bosworth, M. and C. Hoyle (ed.) What is Criminology? Oxford: Oxford University Press.

Cain, M. (1990) ‘Towards Transgression: New Directions in Feminist Criminology', in International Journal of the Sociology of Law, 18:1-18. 
Carrabine, E. (2014) ‘Criminology, Deviance and Sociology’, in Holmwood, J. and J. Scott (eds.) The Palgrave Handbook of Sociology in Britain, Basingstoke: Palgrave MacMillan, pp. 459-487.

Carrabine, E. (2015) 'Contemporary Criminology and the Sociological Imagination', in Frauley, J. (ed.) C. Wright Mills and the Criminological Imagination: Prospects for Creative Inquiry, Farnham: Ashgate, pp.73-98.

Clarke, G. (1981/1990) 'Defending Ski-Jumpers', in Frith, S. and A. Goodwin (eds.) On Record, London: Routledge.

Clarke, R. and M. Felson (2008) (eds.) Routine Activity and Rational Choice, New Brunswick, NJ: Transaction.

Cohen, S. (1980) 'Symbols of Trouble', in Folk Devils and Moral Panics, London: MacGibbon and Kee. $2^{\text {nd }}$ ed.

Cohen, S. (1981/1988) 'Footprints in the Sand: A Further Report on Criminology and the Sociology of Deviance in Britain', in Cohen, S. (ed.) Against Criminology, Oxford: Transaction Books.

Cohen, S. (1988) 'Against Criminology', in Cohen, S. (ed.) Against Criminology, Oxford: Transaction Books.

Currie, E. (1998) Crime and Punishment in America, New York: Metropolitan Books. Downes, D. (1988) 'The Sociology of Crime and Social Control in Britain, 1960-1987', in Rock, P. (ed) A History of British Criminology, Oxford: Clarendon Press.

Ferrell, J., K. Hayward, W. Morrison and M. Presdee (2004) (eds) Cultural Criminology Unleashed, London: Glass House.

Ferrell, J., K. Hayward and J. Young (2008) Cultural Criminology, London: SAGE. Garland, D. (1990) Punishment and Modern Society, Oxford: Oxford University Press. 
Garland, D. and R. Sparks (2000) 'Criminology, Social Theory and the Challenge of Our Times', in Garland, D. and R. Sparks (eds.) Criminology and Social Theory, Oxford: Oxford University Press.

Garland, D. (2011) 'Criminology's Place in the Academic Field', in Bosworth, M. and C. Hoyle (ed.) What is Criminology? Oxford: Oxford University Press.

Gilroy, P. (1987) There Ain't No Black in the Union Jack: The Cultural Politics of Nation and Race, London: Unwin Hyman.

Gilroy, P. (2000) Between Camps: Nations, Cultures and the Allure of Race, London: Penguin.

Gilroy, P. (2004) After Empire: Melancholia or Convivial Culture, London: Routledge. Goffman, E. (1963) Stigma, London: Penguin.

Halford, S. and T. Strangleman (2009) 'In Search of the Sociology of Work: Past, Present and Future', in Sociology, 43(5): 811-828.

Hall, S. C. Critcher, T. Jefferson, J. Clarke and B. Roberts (1978) Policing the Crisis: Mugging, the State and Law and Order, London: Macmillan.

Hall, S. and T. Jefferson (2006) 'Once more around Resistance through Rituals' in Hall, S. and T. Jefferson Resistance through Rituals: Youth Subcultures in post-war Britain, London: Routledge. $2^{\text {nd }}$ edition.

Hall, S. and S. Winlow (2007) 'Cultural Criminology and Primitive Accumulation: A Formal Introduction for Two Strangers who really should become more Intimate', in Crime, Media, Culture, 3(1):82-90.

Hall, S. and S. Winlow (2012) 'Introduction: The Need for New Directions in Criminological Theory', in Hall, S. and S. Winlow (eds) New Directions in Criminology, London: Sage. Hall, S. and S. Winlow (2015) Revitalizing Criminological Theory: Towards A New UltraRealism, London: Routledge. 
Hannah-Moffatt, K. (2011) ‘Criminological Cliques: Narrowing Dialogues, Institutional Protectionism, and the Next Generation', in Bosworth, M. and C. Hoyle (ed.) What is Criminology? Oxford: Oxford University Press.

Hayward, K. (2002) 'The Vilification and Pleasures of Youthful Transgression', in Muncie, J., G. Hughes, and E. McLaughlin (eds.) Youth Justice: Critical Readings, London: Sage. Hebdige, D. (1979) Subculture: The Meaning of Style Hebdige, D. (1988) Hiding in the Light, London: Comedia.

Hobbs, D. (2012) “"It was never about the money”: Market Society, Organised Crime and UK Criminology', in Hall, S. and S. Winlow (eds.) New Directions in Criminological Theory, London: Routledge.

Hobbs, D. (2013) Lush Life, Oxford: Oxford University Press.

Hodkinson, P. (2012) 'Beyond Spectacular Specifics in the Study of Youth (Sub)cultures', in Journal of Youth Studies, 15(5):557-572.

Holmwood, J. (2010) ‘Sociology’s Misfortune: Disciplines, Interdisciplinarity and the Impact of Audit Culture', in The British Journal of Sociology, 61(4):639-658.

Jaffe, R. (2012) 'Talkin' 'bout the Ghetto: Popular Culture and Urban Imaginaries of Immobility', in International Journal of Urban and Regional Research 36(4):674-688. Jenks, C. (2003) Transgression, London: Routledge.

Jervis, J. (1999) Transgressing the Modern: Explorations in the Western Experience of Otherness, Oxford: Blackwell.

Katz, J. (1988) The Seductions of Crime, New York: Basic Books.

Liazos, A. (1972) 'The Poverty of the Sociology of Deviance: Nuts, Sluts and Preverts', in Social Problems 20(1):103-20. 
Loader, I. and R. Sparks (2012) 'Situating Criminology: On the Production and Consumption of Knowledge about Crime and Justice', in Maguire, M., R. Morgan and R. Reiner (eds.) The Oxford Handbook of Criminology, 5th Ed., Oxford: Clarendon Press.

Lyng, S. (1990) 'Edgework', in American Journal of Sociology 94(5):851-86.

Matthews, R. (2009) ‘Beyond “So What” Criminology: Rediscovering Realism', in Theoretical Criminology, 13:341-362

Matthews, R. (2014) 'Cultural Realism?’, in Crime, Media, Culture, 10(3):203-214.

McRobbie, A. (1981) 'Settling Accounts with Subcultures: A Feminist Critique', in Bennett, T., G. Martin, C. Mercer and J. Woollacott (eds.) Popular Culture: Past and Present. London: Open University Press.

Miller, E. (1991) 'Assessing the Risk of Inattention to Class, Race, Ethnicity and Gender: Comment on Lyng', in American Journal of Sociology, 96:1530-1534.

Mills, C. (1943/63) 'The Professional Ideology of Social Pathologists', in Horowitz, I. (ed.) Power, Politics and People: The Collected Essays of C. Wright Mills, New York: Oxford University Press.

Mills, C. (1959) The Sociological Imagination, Oxford: Oxford University Press.

Pearson, G. (1975) The Deviant Imagination, London: Macmillan.

Presdee, M. (2000) Cultural Criminology and the Carnival of Crime, London: Routledge. Redhead, S. (1997) Subculture to Clubcultures, Oxford: Blackwell.

Reiner, R. (2012) 'Political Economy and Criminology: Return of the Repressed', in Hall, S. and S. Winlow (eds) New Directions in Criminology, London: Sage.

Rock, P. (1988) 'The Present State of Criminology in Britain', in Rock, P. (ed) A History of British Criminology, Oxford: Clarendon Press.

Rock, P. (2011) “"What Have We Done?” Trends in Criminological Theorising', in Acta Criminologica 24(1):19-43. 
Sampson, R., S. Raudenbush and F. Earls (1997) 'Neighbourhoods and Violent Crime: A Multilevel Study of Collective Efficacy', in Science, 277:918-24.

Savage, M. (2010) 'Unpicking Sociology’s Misfortunes', in British Journal of Sociology, 61(4):659-665.

Scott, J. (2005) 'Sociology and its Others: Reflections on Disciplinary Specialization and Fragmentation', in Sociological Research Online, 10(1), URL (consulted July 2015):http://www.socresonline.org.uk/10/1/scott.html.

Short, F. with L. Hughes (2007) 'Criminology, Criminologists, and the Sociological Enterprise', in C. Calhoun (ed.) Sociology in America: A History, Chicago: University of Chicago Press.

Stanley, L. (2005) ‘A Child of Its Time: Hybridic Perspectives on Othering in Sociology', in Sociological Research Online, 10(3) <http://www.socresonline.org.uk/10/3/stanley.html>. Sumner, C. (1994) The Sociology of Deviance: An Obituary, Milton Keynes: Open University Press.

Sweetman, P. (2013) 'Structure, Agency, Subculture: The CCCS, Resistance through Rituals, and "Post-Subcultural” Studies', in Sociological Research Online, 18 (4) 22 <http://www.socresonline.org.uk/18/4/22.html> Taylor, I. (1999) Crime in Context, Cambridge: Polity. Taylor, I., P. Walton and J. Young (1973) The New Criminology, London: Routledge and Kegan Paul.

Turner, S. (2009) 'The Future of Social Theory', in B. Turner (ed.) The New Blackwell Companion to Social Theory, Oxford: Wiley-Blackwell.

Urry, J. (1981) 'Sociology as a Parasite: Some Vices and Virtues', in Abrams, P. R. Deem, J. Finch, and P. Rock Practice and Progress: British Sociology, 1950-1980. London: George Allen and Unwin. 
Urry, J. (2005) 'Beyond the "Science” of Society', Sociological Research Online 10(2),

URL (consulted July 2015): http://www.socresonline.org.uk/10/2/urry.html.

Willis, P. (1977) Learning to Labour, London: Saxon House.

Winlow, S. and R. Atkinson (2013) 'Introduction', in Winlow, S. and R. Atkinson (eds.) New

Directions in Crime and Deviancy, Oxon: Routledge.

Young, J. (1998) 'Breaking Windows: Situating the New Criminology', in Walton, P. and J.

Young (eds.) The New Criminology Revisited, London: Macmillan.

Young, J. (2007) The Vertigo of Late Modernity, London: SAGE.

Young, J. (2011) The Criminological Imagination, Cambridge: Polity.

Young, J. (2013) 'Introduction to $40^{\text {th }}$ Anniversary Edition', in Taylor, I., P. Walton and J.

Young (1973/2013) The New Criminology, Oxon: Routledge.

\section{Author biography}

Eamonn Carrabine is a Professor of Sociology at the University of Essex. His books include

Crime in Modern Britain (co-authored, 2002), Power, Discourse and Resistance: A

Genealogy of the Strangeways Prison Riot (2004), Crime, Culture and the Media (2008) and

Crime and Social Theory (forthcoming). His co-authored textbook Criminology: A

Sociological Introduction is now in its third edition and he currently a holds a Leverhulme

Trust Major Research Fellowship to research his project 'The Iconography of Punishment:

From Renaissance to Modernity'.

\footnotetext{
${ }^{1}$ This is not to say that there was no British sociological work on crime and deviance before then, but these contributions are overshadowed by the intellectual pyrotechnics associated with the NDC. The reasons for this are discussed in Carrabine (2014).
} 